\title{
EVALUATION OF NUTRIENT USE EFFICIENCY (NUE) PARAMETERS FOR NITROGEN AND ZINC FERTILIZERS ON WHEAT PLANT IN ASSIUT GOVERNORATE, EGYPT.
}

Fahmy, F.M., El-Sebaey, M.M.; and Nasef, M.K.

Soils, Water and Environ. Res. Inst., Agric.Res.Center, Giza, Egypt.

\section{ABSTRACT}

Field experiment was conducted to evaluate the use efficiency of nitrogen and zinc on growth and yield parameters of wheat plant. This work was carried out in clayey textured soil at Show village, Abnob district, Assiut Governorate, during the year, 2011-2012 season. A randomized complete block design experiment with three replicates was carried out using wheat (Var.Sids 8) as plant indicator. The experiment included 25 treatments i.e., five nitrogen application rates $\left(0,50,75,100\right.$ and $\left.125 \mathrm{~kg} \mathrm{~N}^{-1}\right)$ as urea which was in two equal doses(after 25 and 40 days of sowing) at the time of irrigation. Also, five zinc application rates $\left(0,5,10,15\right.$ and $\left.20 \mathrm{~kg} \mathrm{Zn} \mathrm{fed}^{-1}\right)$ as $\mathrm{ZnSO}_{4}$ by broadcasting in powder form mixed with the soil at seedbed preparation.

Application of $\mathrm{N}$ at rates of $50,75,100$ and $125 \mathrm{mg} \mathrm{kg}^{-1}$ resulted in percentage increases in yield of grains equivalent to $258,223,212$ and $263 \%$, respectively as compared with the corresponding values of the control plants $(0.0$ level $\mathrm{N})$. In case of straw, the corresponding increases were 227, 252, 250 and $199 \%$, respectively. The results show that application of $\mathrm{Zn}$ up to $10 \mathrm{mg} \mathrm{kg} \mathrm{kg}^{-1}$ soil has a positive effect on grain yield of wheat. Addition of 5 and $10 \mathrm{mg} \mathrm{Zn} \mathrm{kg}^{-1}$ soil caused significant (0.05) increases in yield; the increases were 51 and $26 \%$, respectively over the control treatments.

Concerning the interaction between nitrogen and zinc application, data showed that the 1000 grain weight values increased by using different levels of $\mathrm{N}$ and $\mathrm{Zn}$ compared with the control, where the $50 \mathrm{~kg}$ $\mathrm{N}$ fed ${ }^{-1}$ with $10 \mathrm{~kg} \mathrm{Zn} \mathrm{fed}^{-1}$ caused significant increases in the yield and the best treatment of the 1000 grain weight grams. On the other side, increasing $\mathrm{Zn}$ application over $10 \mathrm{~kg} \mathrm{fed}^{-1}$ caused pronounced and significant decreases in weight yield. The interaction effect of $\mathrm{N}$ and $\mathrm{Zn}$ treatment on grains and straw attained its highest values conceded, with of $125 \mathrm{~kg} \mathrm{~N}$ and $5 \mathrm{~kg} \mathrm{Zn} \mathrm{fed}^{-1}$ and $75 \mathrm{~kg} \mathrm{~N} \mathrm{fed}^{-1}+5 \mathrm{~kg} \mathrm{Zn} \mathrm{fed}^{-1}$, respectively. The results showed that the rate of $50 \mathrm{~kg} \mathrm{~N} / \mathrm{fed}$, gave the best Physiological efficiency (PE) compared with other treatments (i.e., 75,100 and $125 \mathrm{~kg} \mathrm{~N} / \mathrm{fed}$ ). While, the values were increased as the application rates of $\mathrm{Zn}$ increased (i.e. 5 and $10 \mathrm{~kg}$ zinc/fed), and then decreased with increasing $\mathrm{Zn}$ application (i.e. 15 and $20 \mathrm{~kg} \mathrm{Zn} / \mathrm{fed}$ ). The best physiological efficiency (PE) accompanied with the rate of 10 $\mathrm{kg}$ zinc/fed.

Key words: Nutrien, Zinc, Wheat plant.

\section{INTRODUCTION}

Wheat is the most important cereal crop in Egypt and the world. Different nutrition elements are required in order to grow wheat sufficiently such as nitrogen, phosphorous, potassium, calcium and magnesium, but in different quantities (Lucas 1996). Nitrogen is a macro element that has an important role within

Fayoum J. Agric. Res. \& Dev., Vol. 27, No.1, January, 2013 
molecules, enzymes, co-enzymes, nucleic acid and cytochromes (Uhart and Andrade 1995). Verma and Bhagat (1990) reported that a decrease of grains yield can be attributed to a lack of nitrogen.

Continuous use of high doses of nitrogenous fertilizers to meet the intensive cultivation of high yielding crop varieties during the last few decades have resulted in widespread Zn deficiency in almost all soil types (Verma and Bhagat, 1990). Egypt is a wheat-growing nation and wheat is the main staple food and major cereal crop in Egypt. So, application of micronutrients i.e., $\mathrm{Zn}$ is an option for increasing yield. It is evident that for obtaining increased yield of wheat, $\mathrm{Zn}$ status of the soils should be improved using $\mathrm{Zn}$ fertilizers (Shaheen et al., 2007).

Baligar et al (2001) reported that many agricultural soils of the world are deficient in one or more of the essential nutrients needed to support healthy plants. Additions of fertilizers and/or amendments are essential for a proper nutrient supply and maximum yields. Estimates of overall efficiency of applied fertilizer have been reported to be about or lower than $50 \%$ for $\mathrm{N}$, less than $10 \%$ for $\mathrm{P}$, and about $40 \%$ for K. Plants that are efficient in absorption and utilization of nutrients greatly enhance the efficiency of applied fertilizers, reducing cost of inputs, and preventing losses of nutrients to ecosystems. Inter- and intra-specific variation for plant growth and mineral nutrient use efficiency (NUE) are known to be under genetic and physiological control and are modified by plant interactions with environmental variables. There is need for breeding programs to focus on developing cultivars with high NUE. Identification of traits such as nutrient absorption, transport, utilization, and mobilization in plant cultivars should greatly enhance fertilizer use efficiency. The development of new cultivars with higher NUE, coupled with best management practices (BMPs) will contribute to sustainable agricultural systems that protect and promote soil, water and air quality.

Nutrient efficiency as the ability of genotype/cultivar to acquire nutrients from growth medium and/or to incorporate or utilize them in the production of shoot and root biomass or utilizable plant material (seed, grain, fruits, forage). Higher Nutrient Use Efficiency (NUE) by plants could reduce fertilizer input costs, decrease the rate of nutrient losses, and enhance crop yields. Genetic and physiological components of plants have profound effects on their abilities to absorb and utilize nutrients under various environmental and ecological conditions. Genetic, morphological, and physiological plant traits and their interactions with external factors such as soil moisture and temperature, light, best management practices, soil biological, and fertilizer materials need to be more thoroughly evaluated to improve the NUE in plants (Blair 1993).

The evaluation of NUE is useful to differentiate plant species, genotype and cultivars for their ability to absorb and utilize nutrients for maximum yields. The NUE is based on (a) uptake efficiency (acquire from soil, influx rate into roots, influx kinetics, radial transport in roots are based on root parameters per weight or length and uptake is also related to the amounts of the particular nutrient applied or present in soil), (b) incorporation efficiency (transports to shoot and leaves are based on shoot parameters) and (c) utilization efficiency (based on remobilization, whole plant i.e. root and shoot parameters), Gerloff and Gablemen (1983); and Baligar and Fageria (1997).

The present investigation was undertaken to study the evaluation of Nutrient Use Efficiency (NUE) of nitrogen and zinc fertilizers on growth and yield parameters of wheat crop in Assiut Governorate, Egypt.

Fayoum J. Agric. Res. \& Dev., Vol. 27, No.1, January, 2013 


\section{MATERIALS AND METHODS}

Field experiment was conducted to evaluate the effect of nitrogen and zinc fertilizers on growth and yield parameters, of wheat crop.

This work was carried out at Show village, Abnob District, Assiut Governorate, Egypt which lies between $30^{\circ} 45^{-}$to $31^{\circ} 24^{-}$, North and $70^{\circ} 44^{-}$to $71^{\circ} 50^{-}$, East, during, 2011-2012 season. The experimental soil was a Typic

Torrifluvent, fine loamy, mixed, hyperthermic. Soil texture was clay having the

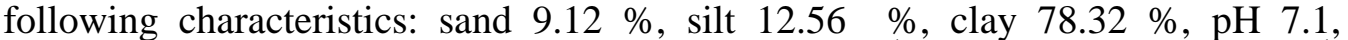
Organic matter $2.13 \%, \mathrm{CaCO}_{3} 1.7 \%$, EC $2.05 \mathrm{dSm}^{-1}$, available $\mathrm{N} 17.5 \mathrm{mg} \mathrm{kg}^{-1}$, AB-DTPA extractable $\mathrm{Zn} 0.23 \mathrm{mg} \mathrm{kg}^{-1}$.

The experiment layout was a randomized complete block design with three replicates using wheat plants (Var. Sids 8) as plant indicator. It included 25 treatments i.e., five nitrogen application rates $(0,50,75,100$ and $125 \mathrm{~kg}$ N/Fadden) as urea which was applied in two equal doses after 25 and 40 days of sowing at the time of irrigation and five zinc application rates $(0,5,10,15$ and $20 \mathrm{~kg} / \mathrm{Fadden})$ as $\mathrm{ZnSO}_{4}$ by broadcasting in powder form mixed with soil at the time of seedbed preparation. The experiment included 75 plots of $\left(3.0 * 3.0 \mathrm{~m}^{2}\right)$ with between plots and total area of about $675 \mathrm{~m}^{2}$ A drill hand machine on 26 Nov 2011 was used for sowing. The recommended doses of $\mathrm{P}$ and $\mathrm{K}$ were used at $100 \mathrm{~kg} \mathrm{P}_{2} \mathrm{O}_{5}$ and $60 \mathrm{~kg}$ $\mathrm{K}_{2} \mathrm{O}$ fed $^{-1}$ in all treatments.

The crop was harvested at maturity (7 May 2012), grains and straw yields were determined. The samples of grains and straw were rinsed with tap water, then with distilled water and finally were kept at $70^{\circ} \mathrm{C}$ for $48 \mathrm{~h}$. The dried and ground plant materials $(0.5 \mathrm{~g})$ were digested with sulphuric acid and hydrogen peroxide according to Wolf (1982). Nitrogen was determined using macro Kjeldhal method described by Klute (1986) and $\mathrm{Zn}$ was determined with atomic absorption spectrophotometer ("GBC", 932 AA), Jackson (1976).

Soil physical and chemical properties were conducted according to Kulte (1986) and Page et al. (1982). Zinc was extracted by AB-DTPA $\left(1 \underline{N} \mathrm{NH}_{4} \mathrm{HCO}_{3}+\right.$ $0.005 \underline{M}$ diethylenetriaminepenta acetic acid) according to (Soltanpour, 1985) and was determined by the atomic absorption spectrophotometer, "GBC", 932 AA, Jackson (1976).

Statistical differences were determined by analysis of variance (ANOVA) followed by the least significant difference (LSD) test for multiple comparisons among groups using MSTAT-C software (Scott, 1999). Differences were considered statistically significant at $(0.05)$.

Nutrient Use Efficiency (NUE): According to Fageria, et al, 1996)

1- Agronomic efficiency (AE): is defined as the economic production obtained per unit of nutrient applied. It can be calculated by:

$A E\left(k g \mathbf{k g}^{-1}\right)=\frac{\left(\text { Yield } F_{s} k g-Y i e l d C_{s} k g\right)}{\text { Quantity of mutrient applied, } k g}$

Where $\mathbf{F}$ is plants receiving fertilizer and $\mathbf{C}$ is plants receiving no fertilizer.

2- Physiological efficiency (PE) is defined as the biological production obtained per unit of nutrient absorbed. It can be calculated by:

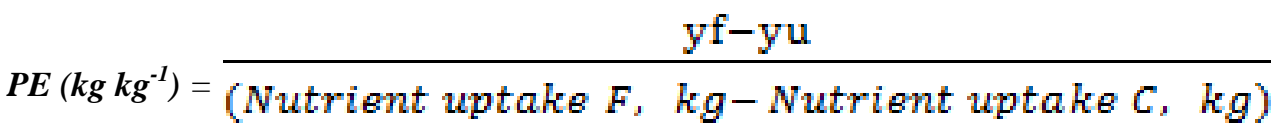

Fayoum J. Agric. Res. \& Dev., Vol. 27, No.1, January, 2013 
Where $\mathbf{y f}$ is the total dry matter yield of the fertilized crop $(\mathrm{kg})$, yu is the total dry matter yield of the unfertilized crop $(\mathrm{kg})$.

3- Apparent nutrient recovery efficiency (ANR) has been used to reflect plant ability to acquire applied nutrient from soil. It can be calculated by:

\section{(Nutrient uptake $F_{s} \mathrm{~kg}$-Nutrient uptake $\left.C_{s} \mathrm{~kg}\right) \times 100$ \\ ANR $=\frac{\text { Quantityof nutrientapplied, } \mathrm{kg}}{=} \%$}

\section{RESULTS AND DISCUSSION \\ Yield of wheat plants:}

Results presented in Table (1) show that the grains and straw weight yields of wheat were significantly (0.05) increased progressively with application of $\mathrm{N}$. The ascending application rates of $\mathrm{N}\left(50,75,100\right.$ and $\left.125 \mathrm{mg} \mathrm{kg}^{-1}\right)$ were coupled with increases in yield of grains equivalent to 258, 223, 212 and $263 \%$ respectively as compared with the control $(0.0 \mathrm{~kg} \mathrm{~N} / \mathrm{fed})$. In case of straw, the corresponding increases for the aforementioned rates were 227, 252, 250 and 199 $\%$, respectively. The highest increase in straw of wheat were associated with treatment receiving $100 \mathrm{mg} \mathrm{kg}^{-1} \mathrm{~N}$. These results are agreement with those obtained by Verma and Bhagat, 1990 .

Table (1). Effect of applied zinc and nitrogen rates on dry matter yield and 1000 grains of wheat plant.

\begin{tabular}{|c|c|c|c|c|c|c|}
\hline \multirow{3}{*}{$\begin{array}{c}\text { Applied N } \\
\text { (kg/fed) }\end{array}$} & \multicolumn{6}{|c|}{ Applied Zn (kg/fed) } \\
\hline & \multicolumn{6}{|c|}{ Grain yield (ton \fed) } \\
\hline & 0.0 & 5.0 & 10.0 & 15.0 & 20.0 & Mean \\
\hline 0.0 & 0.58 & 0.86 & 0.24 & 0.34 & 0.21 & 0.48 \\
\hline 50 & 1.26 & 2.36 & 1.82 & 1.8 & 1.39 & 1.73 \\
\hline 75 & 1.38 & 1.66 & 2.02 & 1.37 & 1.3 & 1.56 \\
\hline 100 & 1.73 & 1.86 & 2.09 & 0.96 & 0.89 & 1.51 \\
\hline 125 & 1.85 & 2.91 & 1.65 & 1.71 & 1.03 & 1.83 \\
\hline Mean & 1.36 & 1.93 & 1.61 & 1.24 & 0.96 & \\
\hline LSD. 0.05 & \multicolumn{2}{|c|}{$\mathrm{Zn}=0.0013$} & \multicolumn{3}{|c|}{$\mathrm{Zn} * \mathrm{~N}_{2}=0.0926$} & $\mathrm{~N}_{2}=0.0013$ \\
\hline & \multicolumn{6}{|c|}{ Straw yield (ton $\backslash$ fed) } \\
\hline 0.0 & 1.61 & 1.51 & 1.14 & 0.80 & 0.46 & 1.10 \\
\hline 50 & 3.25 & 3.86 & 4.41 & 2.67 & 2.88 & 3.41 \\
\hline 75 & 3.31 & 4.71 & 4.14 & 3.17 & 3.00 & 3.66 \\
\hline 100 & 3.61 & 4.25 & 4.15 & 3.60 & 2.61 & 3.64 \\
\hline 125 & 3.39 & 3.43 & 3.25 & 3.24 & 2.75 & 3.01 \\
\hline Mean & 3.034 & 3.55 & 3.41 & 2.69 & 2.34 & \\
\hline LSD. 0.05 & \multicolumn{2}{|c|}{$\mathrm{Zn}=0.066$} & \multicolumn{2}{|c|}{$\mathrm{Zn} * \mathrm{~N}_{2}=0.148$} & \multicolumn{2}{|c|}{$\mathrm{N}_{2}=0.066$} \\
\hline & \multicolumn{6}{|c|}{1000 grains weight (grams) } \\
\hline 0.0 & 36.46 & 25.07 & 32.73 & 22.86 & 26.62 & 26.75 \\
\hline 50 & 46.45 & 48.56 & 50.89 & 49.17 & 43.31 & 47.68 \\
\hline 75 & 49.22 & 49.49 & 50.65 & 49.05 & 49.12 & 49.51 \\
\hline 100 & 46.15 & 49.76 & 50.13 & 50.26 & 49.46 & 49.15 \\
\hline 125 & 49.31 & 50.22 & 50.25 & 50.58 & 49.93 & 50.058 \\
\hline Mean & 45.52 & 44.63 & 46.93 & 44.38 & 43.69 & \\
\hline LSD. 0.05 & \multicolumn{2}{|c|}{$\mathrm{Zn}=1.08$} & \multicolumn{2}{|c|}{$\mathrm{Zn} * \mathrm{~N}_{2}=2.418$} & \multicolumn{2}{|c|}{$\mathrm{N}_{2}=1.08$} \\
\hline
\end{tabular}

The addition of 5 and $10 \mathrm{mg} \mathrm{Zn} \mathrm{kg}^{-1}$ soil caused positive and significant $(0.05)$ increases in yield; (51 and $26 \%$ of control treatment, as mean, respectively). On the other side, increasing $\mathrm{Zn}$ application over $10 \mathrm{mg} \mathrm{kg}^{-1}$ caused pronounced and significant decreases in the yields. The magnitudes of decrease at 15 and $20 \mathrm{mg}$

Fayoum J. Agric. Res. \& Dev., Vol. 27, No.1, January, 2013 
$\mathrm{kg}^{-1}$ applications in grains were 3.5 and $25 \%$ of control treatment, as mean, respectively. Application of $\mathrm{Zn}$ at rates of 5,10, 15 and $20 \mathrm{mg} \mathrm{kg}^{-1}$ caused increases in yield of straw equivalent to $68,62,25$ and $11 \%$ respectively as compared with the corresponding values of zero application treatment (as mean).

Comparisons of means for effects of interactions between nitrogen and zinc on weights of either grains or straw of wheat showed significant effects. The highest effect of the interaction for grains was associated with treatment of (125 mg $\mathrm{N} \mathrm{kg}^{-1}+5 \mathrm{mg} \mathrm{Zn} \mathrm{kg}^{-1}$ ), while the corresponding treatment for straw was (75 mg N $\left.\mathrm{kg}^{-1}+5 \mathrm{mg} \mathrm{Zn} \mathrm{kg}{ }^{-1}\right)$.

Data in Table 1 indicate that the 1000 grain weight had significantly $(0.05)$ affected by different application levels in the tested soil. The results reveal that the 1000 grain weight values are significantly $(0.05)$ increased by increasing nitrogen addition rates, where the $125 \mathrm{~kg}$ nitrogen fertilizer application soil gave the highest values. In case of zinc rates, 1000 grain weight significant vales are (0.05) increased by increasing zinc addition rates, where the rate of $10 \mathrm{~kg} \mathrm{Zn} \mathrm{fed}^{-1}$ in the tested soil gave the highest values. Concerning the interaction between nitrogen and zinc application, data show that the 1000 grain weight values increased by using different levels of $\mathrm{N}$ and $\mathrm{Zn}$ compared with the control, where the rate of (50 $\mathrm{kg} \mathrm{N} / \mathrm{fed}$, and $10 \mathrm{~kg} \mathrm{Zn} \mathrm{fed}^{-1}$ ) caused significant and the best treatment. These results are in agreement with Khan, et al., (2008)

Nitrogen uptake $\left(\mathrm{kg} \mathrm{fed}^{-1}\right)$ by wheat plants:

Data presented in Table (2) indict that application of nitrogen fertilizers resulted in significant progressive increases in the uptake of $\mathrm{N}$ in both grains and straw of wheat. Application of $\mathrm{N}$ at rates of $50,75,100$ and $125 \mathrm{mg} \mathrm{kg}^{-1}$ resulted in percentage increases in $\mathrm{N}$ uptake in grains equivalent to 270,256 , 281 and $296 \%$ of control treatment, respectively. In case of straw, the

Table (2): Nitrogen uptake (kg. fed ${ }^{-1}$ ) by wheat plant on the studied soil.

\begin{tabular}{|c|c|c|c|c|c|c|}
\hline \multirow{3}{*}{$\begin{array}{l}\text { Applied } \\
\mathrm{N}(\mathrm{kg} / \mathrm{fed})\end{array}$} & \multicolumn{6}{|c|}{ Applied Zn (kg/fed) } \\
\hline & 0 & 5 & 10 & 15 & 20 & Main \\
\hline & \multicolumn{6}{|c|}{ kg N. fed ${ }^{-1}$ (Grains) } \\
\hline 0.0 & 0.66 & 4.27 & 2.47 & 1.56 & 1.14 & 2.02 \\
\hline 50 & 5.17 & 12.0 & 6.79 & 8.11 & 5.37 & 7.488 \\
\hline 75 & 5.18 & 11.6 & 8.52 & 5.98 & 4.74 & 7.204 \\
\hline 100 & 9.17 & 9.45 & 9.58 & 6.45 & 3.87 & 7.722 \\
\hline 125 & 6.1 & 9.77 & 8.14 & 8.41 & 2.70 & 8.024 \\
\hline Main & 5.26 & 9.41 & 7.10 & 6.10 & 3.56 & \\
\hline \multirow[t]{2}{*}{ LSD. 0.05} & \multicolumn{2}{|c|}{$\mathrm{Zn}=0.373$} & \multicolumn{2}{|c|}{$Z n * N_{2}=0.844$} & \multicolumn{2}{|c|}{$\mathrm{N}_{2}=0.373$} \\
\hline & \multicolumn{6}{|c|}{ kg N. fed ${ }^{-1}$ (Straw) } \\
\hline 0.0 & 0.43 & 2.71 & 2.32 & 1.35 & 1.21 & 1.60 \\
\hline 50 & 4.23 & 5.15 & 5.73 & 3.88 & 4.42 & 4.682 \\
\hline 75 & 5.18 & 5.7 & 6.62 & 4.76 & 4.29 & 5.310 \\
\hline 100 & 6.13 & 5.19 & 6.78 & 4.79 & 4.24 & 5.426 \\
\hline 125 & 5.62 & 7.35 & 4.46 & 3.71 & 2.39 & 4.704 \\
\hline Main & 4.32 & 5.22 & 5.18 & 3.70 & 3.31 & \\
\hline LSD. 0.05 & \multicolumn{2}{|c|}{$\mathrm{Zn}=0.302$} & $n * N_{2}$ & 898 & \multicolumn{2}{|c|}{$\mathrm{N}_{2}=0.302$} \\
\hline
\end{tabular}

Fayoum J. Agric. Res. \& Dev., Vol. 27, No.1, January, 2013 
corresponding increases were 221, 264, 272 and $222 \%$, respectively, compared with the control plants $(0.0$ level of $\mathrm{N})$. The highest increases in the $\mathrm{N}$ uptake in grains and straw of wheat were associated with treatments received 125 and 100 $\mathrm{mg} \mathrm{N} \mathrm{kg} \mathrm{fed}{ }^{-1}$, respectively.

However, the results show that application of $\mathrm{Zn}$ up to $5 \mathrm{mg} \mathrm{kg}^{-1}$ soil had a positive effect on the uptake of $\mathrm{N}$. Addition of 5 or $10 \mathrm{mg} \mathrm{Zn} \mathrm{kg}{ }^{-1}$ soil caused significant (0.05) increases in the yield; (i.e. 49.2 and $12.7 \%$ over the control treatments).

On the other side, increasing $\mathrm{Zn}$ application over $10 \mathrm{mg} \mathrm{kg}^{-1}$ resulted in pronounced and significant decreases in the yields. The magnitude of $\mathrm{N}$ decrease in grain yield at application rates of 15 and $20 \mathrm{~kg} \mathrm{Zn} \mathrm{fed}^{-1}$, were -3.1 and $-5.8 \%$ of control treatment, respectively. Application of $\mathrm{Zn}$ at rates of 5, 10,15 and $20 \mathrm{mg} \mathrm{kg}^{-1}$ resulted in percentage increase in the yield of straw equivalent to $20.8,19.9,-14.3$ and $-26.62 \%$ of control treatment, respectively. These results are in agreement with these obtained by Khan $\boldsymbol{e t}$ al (2008), who found that all applications of zinc sulphate gave economic increases in margins over costs but the application of $5 \mathrm{~kg} \mathrm{ha}^{-\mathrm{P}}$ gave the highest marginal rate of return.

Data show that the uptake of $\mathrm{N}$ in both grains and straw of wheat increased significantly compared with the control due to the interaction effects between zinc and nitrogen fertilizers. The highest effect of interaction was associated with treatment of $50 \mathrm{~kg} \mathrm{~N} \mathrm{fed}{ }^{-1}+5 \mathrm{~kg} \mathrm{Zn} \mathrm{fed}^{-1}$ for grains, while for straw, the corresponding treatment was $125 \mathrm{~kg} \mathrm{~N}^{-1} \mathrm{~d}^{-1}+5 \mathrm{~kg} \mathrm{Zn} \mathrm{fed}^{-1}$ soil.

Zinc uptake (g.fed ${ }^{-1}$ ) by wheat plants:

Data presented in Table (3) reveal that application of zinc fertilizer resulted in significant increases in the uptake of zinc by both grains and straw of wheat. The increases were progressive coincide with increasing the rate of added

Table (3): Zinc Uptake (gm. Fed ${ }^{-1}$ ) by wheat plants in the studied soil.

\begin{tabular}{|c|c|c|c|c|c|c|}
\hline \multirow{3}{*}{$\begin{array}{c}\text { Applied N } \\
(\mathrm{kg} / \mathrm{fed})\end{array}$} & \multicolumn{6}{|c|}{ Applied Zn (kg/fed) } \\
\hline & 0.0 & 5.0 & 10.0 & 15.0 & 20.0 & Main \\
\hline & \multicolumn{6}{|c|}{ gm. Fed ${ }^{-1}$ (Grains) } \\
\hline 0.0 & 15.4 & 165 & 94.1 & 90.6 & 57.98 & 84.6 \\
\hline 50 & 65.5 & 564 & 455 & 488 & 383.4 & 447.0 \\
\hline 75 & 109 & 372 & 528 & 472 & 381.4 & 416.8 \\
\hline 100 & 233 & 430 & 519 & 296 & 332.1 & 353.0 \\
\hline 125 & 325 & 718 & 450 & 510 & 252 & 451.0 \\
\hline Main & 150 & 450 & 409.2 & 371.3 & 372 & \\
\hline LSD. 0.05 & \multirow{2}{*}{\multicolumn{2}{|c|}{$\mathrm{Zn}=19.8$}} & \multicolumn{2}{|c|}{$\mathrm{Zn} * \mathrm{~N}_{2}=44.28$} & \multicolumn{2}{|c|}{$\mathrm{N}_{2}=19.8$} \\
\hline & & & \multicolumn{4}{|c|}{ gm. Fed ${ }^{-1}$ (Straw ) } \\
\hline 0.0 & 7.58 & 12.9 & 14.5 & 13.7 & 4.18 & 10.6 \\
\hline 50 & 19.5 & 69.4 & 162 & 66 & 36.5 & 70.7 \\
\hline 75 & 28 & 59.5 & 124 & 110 & 72.1 & 78.7 \\
\hline 100 & 45.7 & 53.8 & 124 & 146 & 101 & 94.1 \\
\hline 125 & 57.4 & 23.9 & 79.4 & 84.2 & 87.9 & 66.6 \\
\hline Main & 31.6 & 43.9 & 100.78 & 83.98 & 60.3 & \\
\hline LSD. 0.05 & \multicolumn{2}{|c|}{$\mathrm{Zn}=1.035$} & \multicolumn{2}{|c|}{$\mathrm{Zn} * \mathrm{~N}_{2}=5.475$} & \multicolumn{2}{|c|}{$\mathrm{N}_{2}=1.035$} \\
\hline
\end{tabular}

nitrogen. Application of $\mathrm{N}$ at rates of $50,75,100$ and $125 \mathrm{~kg} \mathrm{~N}^{\mathrm{N}}{ }^{1}$ soil resulted in increases in zinc uptake by grains equivalent to $428,463,317$ and $388 \%$ of control treatment, respectively. In case of straw, the corresponding increases were 567, 642,788 and $478 \%$, respectively. The highest zinc up tike values in grains and straw were associated with treatment receiving 75 and $100 \mathrm{~kg} \mathrm{~N}^{-1} \mathrm{~d}^{-1}$, respectively.

Fayoum J. Agric. Res. \& Dev., Vol. 27, No.1, January, 2013 
While, increasing $\mathrm{Zn}$ application rates, resulted in significant progressive increases in the uptake of zinc by both grains and straw of wheat. As application of $\mathrm{Zn}$ at rates of $5,10,15$ and $20 \mathrm{~kg} \mathrm{fed}^{-1}$ resulted in percentage increases in zinc uptake in grains equivalent to $302,265,232$ and $286 \%$ of control treatment, respectively. In case of straw, the corresponding increases were 66, 282, 218 and 128\%, respectively. The highest increase in grains and straw of wheat were associated with treatments receiving 5 and $10 \mathrm{~kg} \mathrm{fed}^{-1}$, respectively.

Comparisons of means for effects of interactions between zinc and nitrogen on weights of grains and straw of wheat in Table 3 showed that the effects were significant. The highest effect of interaction for grain was associated with treatment of $125 \mathrm{~kg} \mathrm{~N} \mathrm{fed}^{-1}+5 \mathrm{~kg} \mathrm{Zn} \mathrm{fed}^{-1}$. For straw, the corresponding treatment was with $75 \mathrm{~kg} \mathrm{~N}^{-1}+10 \mathrm{~kg} \mathrm{Zn} \mathrm{fed.}^{-1}$

\section{Available values of zinc and nitrogen in the studied soil.}

Data in Table 4 indicate that available values of nitrogen and zinc were affected by different application levels of $\mathrm{N}$ and $\mathrm{Zn}$ fertilizers in the tested soil. With respect to available nitrogen, the results show that nitrogen increased significantly $(0.05)$ by using higher application rates of nitrogen fertilizer, where the rate of $100 \mathrm{~kg} \mathrm{~N} / \mathrm{fed}$, level was significantly (0.05) the best compared with the other treatments. The soil that available nitrogen values after harvest increased through the different interaction application rates of each $\mathrm{N}$ and $\mathrm{Zn}$, where the treatment of $100 \mathrm{~kg} \mathrm{~N} / \mathrm{fed}$ at $20 \mathrm{~kg}$ zinc/fed was better than the other treatments. These results are in agreement with those obtained by Mahmoud et al. (1993) who found that the clay soil of Bahteem farm contained $50 \mathrm{mg} \mathrm{kg}^{-1}$ of available $\mathrm{N}$.

Table (4): Soil available nitrogen and zinc after harvest.

\begin{tabular}{|c|c|c|c|c|c|c|}
\hline \multirow{2}{*}{$\begin{array}{l}\text { Applied N } \\
\text { (kg/fed) }\end{array}$} & \multicolumn{6}{|c|}{ Applied Zn (kg/fed) } \\
\hline & 0.0 & 5.0 & 10.0 & 15.0 & 20.0 & Main \\
\hline \multicolumn{7}{|c|}{ Available $\mathrm{N}_{2}\left(\mathrm{mg} . \mathrm{kg}^{-1}\right)$} \\
\hline 0.0 & 3.67 & 4.53 & 3.02 & 3.57 & 5.57 & 4.07 \\
\hline 50 & 30.6 & 46.4 & 43.1 & 52.5 & 43.5 & 43.22 \\
\hline 75 & 43.0 & 50.3 & 47.2 & 37.4 & 53.1 & 46.20 \\
\hline 100 & 42.8 & 53.6 & 51.4 & 48.4 & 61.5 & 51.54 \\
\hline 125 & 38.8 & 53.0 & 52.3 & 54.4 & 53.0 & 50.30 \\
\hline Main & 31.8 & 41.6 & 39.40 & 39.25 & 43.33 & \\
\hline LSD. 0.05 & \multicolumn{2}{|c|}{$\mathrm{Zn}=0.949$} & \multicolumn{2}{|c|}{$Z n * N_{2}=2.124$} & \multicolumn{2}{|c|}{$N_{2}=0.949$} \\
\hline \multicolumn{7}{|c|}{ Available $\mathrm{Zn}\left(\mathrm{mg} . \mathrm{kg}^{-1}\right)$} \\
\hline 0.0 & 0.15 & 0.27 & 0.50 & 0.32 & 0.85 & 0.42 \\
\hline 50 & 0.17 & 0.86 & 0.46 & 0.35 & 1.11 & 0.60 \\
\hline 75 & 0.16 & 0.65 & 0.66 & 0.43 & 0.76 & 0.53 \\
\hline 100 & 0.15 & 0.37 & 0.79 & 0.36 & 0.79 & 0.50 \\
\hline 125 & 0.24 & 0.40 & 0.41 & 0.26 & 0.85 & 0.432 \\
\hline Main & 0.17 & 0.51 & 0.56 & 0.34 & 0.87 & 0.49 \\
\hline LSD. 0.05 & \multicolumn{2}{|c|}{$\mathrm{Zn}=0.008$} & \multicolumn{2}{|c|}{$\mathrm{Zn} * \mathrm{~N}_{2}=0.1975$} & \multicolumn{2}{|c|}{$\mathrm{N}_{2}=0.008$} \\
\hline
\end{tabular}

Fayoum J. Agric. Res. \& Dev., Vol. 27, No.1, January, 2013 
Fahmy, F.M., et al.

The results reveal that available values of zinc in the soil after harvest were increased or decreased due to zinc addition rates. DTPA-extractable zinc ranged widely from 0.15 to $1.11 \mathrm{mg} \mathrm{kg}^{-1}$ in the studied soil. According to Lindsey and Norvell (1978), soils under consideration showed inadequate level (>1.0 mg. $\mathrm{Kg}^{-1}$ ) of available zinc, except soil treatment of $50 \mathrm{~kg} \mathrm{~N}+20 \mathrm{~kg} \mathrm{Zn} /$ fed.

\section{Nutrient Use Efficiency parameters (NUE) for $\mathbf{N}$ fertilizer:}

Data in Table 5 indicate that the Physiological efficiency (PE) $\mathrm{kg} . \mathrm{kg}^{1}$, Agronomic efficiency (AE) $\mathrm{kg} \mathrm{kg}^{-1}$, and Apparent recovery efficiency (ARE) \% values were affected by different application rates of $\mathrm{N}$ and $\mathrm{Zn}$ in the tested soil.

The results show that the rate of $50 \mathrm{~kg} \mathrm{~N} / \mathrm{fed}$ soil, gave the best Physiological efficiency (PE) values compared with the other treatments as mean values. While, increasing the rates of nitrogen application (i.e. 75,100 and $125 \mathrm{~kg} \mathrm{~N} / \mathrm{fed}$ ) decreased their values. Increasing the application rates of $\mathrm{Zn}$ to 5 and $10 \mathrm{~kg}$ zinc /fed soil increased the Physiological efficiency, then decreased with increasing $\mathrm{Zn}$ application to 15 and $20 \mathrm{~kg} \mathrm{Zn} \mathrm{/fed} \mathrm{as} \mathrm{mean} \mathrm{values.} \mathrm{While} \mathrm{the} \mathrm{best} \mathrm{Physiological}$ efficiency (PE) was found at the rate of $10 \mathrm{~kg}$ zinc /fed soil.

Table (5): Nutrient Use Efficiency (NUE) for $\mathrm{N}$ fertilizer.

\begin{tabular}{|c|c|c|c|c|c|c|}
\hline \multirow{2}{*}{$\begin{array}{c}\text { Applied N } \\
\text { (kg/fed) }\end{array}$} & 0 & 5 & 10 & 15 & 20 & Mean \\
\cline { 2 - 7 } & \multicolumn{7}{|c|}{ Physiological Efficiency (PE) kg. kg } \\
\hline 50 & 231.04 & 378.56 & 627.42 & 366.74 & 442.26 & 409.02 \\
75 & 226.53 & 387.59 & 466.66 & 434.22 & 491.86 & 401.37 \\
100 & 193.52 & 482.58 & 420.05 & 410.56 & 438.08 & 388.96 \\
125 & 144.59 & 391.51 & 450.70 & 376.76 & 292.01 & 331.12 \\
\hline Mean & 198.92 & 410.06 & 491.21 & 397.07 & 416.06 & \\
\hline \multicolumn{7}{|c|}{ Agronomic Efficiency (AE) Kg. Kg $\mathrm{Kg}^{-1}$} \\
\hline 50 & 13.6 & 30.00 & 31.60 & 29.20 & 23.60 & 25.60 \\
75 & 6.93 & 18.93 & 23.06 & 15.46 & 17.33 & 16.34 \\
100 & 11.5 & 10.00 & 18.50 & 6.20 & 6.80 & 10.60 \\
125 & 7.04 & 16.40 & 11.28 & 10.96 & 6.56 & 10.44 \\
\hline Mean & 9.76 & 18.83 & 21.11 & 15.45 & 13.57 & \\
\hline \multicolumn{7}{|c|}{ Apparent nutrient recovery efficiency (NRE) } \\
\hline 50 & 13.62 & 20.34 & 15.46 & 18.16 & 16.28 & 17.37 \\
75 & 11.36 & 13.76 & 13.80 & 10.44 & 9.84 & 12.04 \\
100 & 12.21 & 7.75 & 11.57 & 8.33 & 6.46 & 9.66 \\
125 & 11.50 & 8.11 & 6.24 & 7.36 & 8.52 & 8.55 \\
\hline Mean & 12.07 & 12.49 & 11.77 & 11.07 & 10.27 & \\
\hline
\end{tabular}

Nutrient Use Efficiency parameters (NUE) for $\mathbf{Z n}$ fertilizer.

Data in Table (6) show that the rate of $75 \mathrm{~kg} \mathrm{~N}+5 \mathrm{~kg} \mathrm{Zn} / \mathrm{fed}$, gave the best Physiological efficiency (PE) compared with the other treatments. Increasing the application rates of $\mathrm{Zn}$ to 5 and $10 \mathrm{~kg}$ zinc /fed increased the Physiological efficiency, then decreased with increasing $\mathrm{Zn}$ application to 15 and $20 \mathrm{~kg} \mathrm{Zn} / \mathrm{fed}$

Fayoum J. Agric. Res. \& Dev., Vol. 27, No.1, January, 2013 
EVALUATION OF NUTRIENT USE EFFICIENCY (NUE).

soil. If trace elements present at excess levels pose phyto-toxicity and can reduce plant growth and nutrient uptake and eventually reduce NUE (Baligar and Ahlrichs., 1998; and Marschner, 1995). Data in Table 6 show that Agronomic efficiency (AE) $\mathrm{kg} \mathrm{kg}^{-1}$ value was affected by different application rate of $\mathrm{Zn}$. As the application rate of $5 \mathrm{~kg}$ zinc fed $^{-1}$ was the best treatments. Concerning the interaction between $\mathrm{N}$ and $\mathrm{Zn}$, data showed that the $50 \mathrm{~kg} \mathrm{~N}$ at $5 \mathrm{~kg} \mathrm{Zn} \mathrm{fed}^{-1}$ was the best treatment. Also the results in Table (6) show that $\mathrm{Zn}$ Apparent nutrient recovery efficiency (NRE) \% values were affected by the different application rates of nitrogen and zinc fertilizers, as the $50 \mathrm{~kg} \mathrm{~N}^{-1} \mathrm{fed}^{-1}$ was the best treatment. While in case of zinc addition rates, NRE increased as result of addition $5 \mathrm{~kg}$ zinc fed ${ }^{-1}$. As for the interaction, NRE was $50 \mathrm{~kg} \mathrm{~N}$ with $5 \mathrm{~kg} \mathrm{Zn} \mathrm{fed}^{-1}$ was the best treatment $\mathrm{s}$. These results are in as agreement with those obtained by Khan et al (2008).

Table (6): Nutrient Use Efficiency (NUE) for Zn fertilizer.

\begin{tabular}{|c|c|c|c|c|c|}
\hline \multirow{2}{*}{$\begin{array}{c}\text { Applied N } \\
\text { (kg/fed) }\end{array}$} & \multicolumn{5}{|c|}{ Applied Zn (kg/fed) } \\
\cline { 2 - 6 } & 5 & \multicolumn{5}{|c|}{ Physiological Efficiency (PE) kg. kg-1 } & Mean \\
\cline { 2 - 6 } 0.0 & 1162 & -9460 & -16 & -18 & -2083 \\
50 & 3394 & 3052 & 36 & 27 & 1627.25 \\
75 & 5335 & 4667 & -10 & -4.0 & 2497 \\
100 & 3754 & 4388 & -51 & -42 & 2012.25 \\
125 & 3060 & 3060 & -9.0 & -41 & 1517.5 \\
\hline Mean & 2729 & 529.4 & -10.25 & -9.25 & \\
\hline 0.0 & 56 & -34 & -16 & -18.6 & -3.0 \\
\hline 50 & 220 & 56 & 36 & 27 & 85 \\
75 & 56 & 64 & -10 & -4.0 & 26 \\
100 & 26 & 36 & -51 & -42 & -8.0 \\
125 & 212 & -20 & -9.3 & -41 & 36 \\
\hline Mean & 114 & 20 & -8.2 & -7.4 & \\
\hline & \multicolumn{5}{|c|}{ Apparent nutrient recovery efficiency (NRE) } \\
\hline 0.0 & 3.098 & 0.856 & 0.542 & 0.196 & 1.173 \\
\hline 50 & 10.076 & 5.603 & 3.206 & 2.905 & 5.447 \\
75 & 6.298 & 3.149 & 3.103 & 4.293 & 4.211 \\
100 & 4.102 & 2.051 & 1.089 & 0.542 & 1.946 \\
125 & 9.190 & 4.60 & 2.080 & 0.290 & 4.040 \\
\hline Mean & 6.55 & 3.25 & 1.870 & 1.640 & \\
\hline
\end{tabular}

Fayoum J. Agric. Res. \& Dev., Vol. 27, No.1, January, 2013 


\section{REFERENCES}

Baligar, V. C. and J. Ahlrichs. 1998. Nature and distribution of acid soils in the world. Pp. 1-11. In: R.E. Schaffert. Proc. of workshop: Develop an Strategy for Collaborative Research and Dissemination of Technology. Purdue University, W. Lafayette, IN.

Baligar, V.C. and Fageria, N.K. 1997. Nutrient use efficiency in acid soils: Nutrient Management and Plant use Efficiency, (ed.) pp. 75-93.Brazili-an Soil Science Society Compinas, Brazil.

Baligar, V.C.; Fageria, N.K. and He, Z.L. 2001. Nutrient use efficiency in plants. Commun. Soil Sci. Plant Anal., 32(7 \& 8), 921-950.

Blair, G. 1993. Nutrient efficiency-what do we really mean. Genetic Aspects of Plant Mineral Nutrition. pp. 205-213. In: P. J. Randall, E. Delhaize, R. A. Richards, and R. Munns. (eds.), Kluwer Academic Publishers, Dordrecht, the Netherlands.

Craswell, E.T., and P.L.G. Velk. 1979. Fate of fertilizer nitrogen applied to Wetland rice. pp. 175-192. In: IRRI (ed.), Nitrogen and Rice IRRI, Los Banos, Philippines.

Fageria, N.K.; Baligar, V.C. and Jonses, C.A. 1996. Growth and mineral Nutrition of Field Crops. (ed.), Printed Marcel Dekker, Inc. U.S.A. chapter 9, pp. 324- 325.

Gerloff, G.C. and Gabelman, W.H. 1983. Genetic basis of inorganic plant nutrition.pp 453- 480. In: A Lauchli and R L Bieleski. (eds.), Inorganic Plant Nutrition. Encyclopedia and Plant Physiology New Series, Volume 15B. Springer Verlag, New York.

Jackson, M.L. (1967). Soil Chemical Analysis. Prentice Hall of India Ltd; New Delhi.

Khan, M.A.; Fuller, M.P. and Baloch, F.S. 2008. Effect of Soil Applied Zinc Sulphate on Wheat (Triticumaestivum L.) Grown on a Calcareous Soil in Pakistan Cereal Research Communications 36(4), pp. 571-582

Klute, A.; 1986. Methods of Soil Analysis. Part 1. Physical and Mineralogical Methods (Sssa Book Series No 5)

Habtegebrial, K., Sing, B.R., and Haile, M. 2007. Impact of tillage and nitrogen fertilization on yield, nitrogen use efficiency of tef [Eragrostis tef (Zucc.) Trotter] and soil properties. Soil Till. Res. 94:55-63.

Lindsay, W.L. and Norvell, W.A. 1978. Development of DTPA test for Zinc, Iron, manganese and copper. Soil Sci., Soc. Amer. Proc., 421 -216.

Lucas, E.O. 1996. Effect of density and nitrogen fertilizer on the growth and yield of maize (Zea mays L.) in Nigeria. Journal of Agricultural Science 107: 573-578.

Mahmoud, M.H.; Kadry, W.; El-Mallah, M.L. and Mahdy, M.A. 1993. Effect of residual $\mathrm{N}$ in soil on flax and corn successively after sunflower. Egypt. J. Soil Appl. Sci, 8 (7): 111 - 122

Marschner, H. 1995. Mineral Nutrition of Higher Plants. Academic Press, San Diego, CA.

Page, A.L., M,H. Miller and D.R. Keeny 1982. Methods of Soil Analysis, Part II, $2^{\text {nd }}$ edition, American Society of Agronomy Madison.

Fayoum J. Agric. Res. \& Dev., Vol. 27, No.1, January, 2013 
EVALUATION OF NUTRIENT USE EFFICIENCY (NUE).

Scott, P.E. 1999. MSTAT-C software. Crop and Soil Sciences Dept., Michigan State University.

Shaheen, R., Samim, M.K. and Mahmud, R. 2007. Effect of zinc on yield and zinc uptake by wheat on some soils of Bangladesh. J. Soil Nat., 1: 7-14.

Soltanpour, P.N. 1985. Use of AB-DTPA soil test to evaluate elemental availability and toxicity. Comm. Soil Sci. Plant Anal., 16: 323-338.

Uhart, S.A. and Andrade, F.H. 1995. Nitrogen deficiency in maize: carbonnitrogen interaction effects on kernel number and grain yield. Crop Sci., 35:1384-1389.

Verma, T.S. and Bhagat, R.M. 1990. Zinc and nitrogen interaction in wheat grown in limed and unlimed acid alfisol. Fertilizer Research 22:29-35.

Wolf, B. (1982). The comprehensive system of leaf analysis and its use for diagnosing crop nutrient status. Comm. Soil Sci. Plant Anal., 13: $1035-1059$.

Fayoum J. Agric. Res. \& Dev., Vol. 27, No.1, January, 2013 
تقييم معاملات كفاعة أستعمال المغذيات لسمادي النتروجين والزنكت علي نبات القمح في محافظة أسيوظ مصري النترو

فايز مرقص فهمي - محمود محمد السباعي - محمود كامل ناصف الإنف

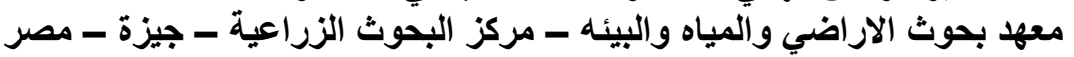

أجريت تجربة حقلية لتقييم كفاءة استخدام المغذيات (NUE) Nutrient Use Efficiency

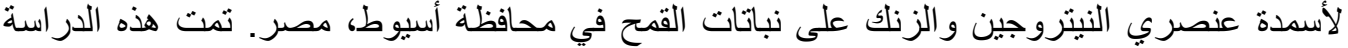

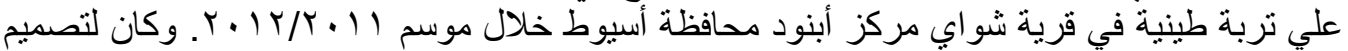

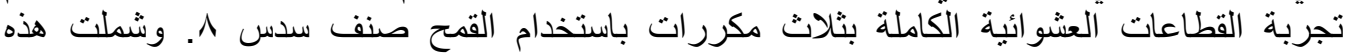

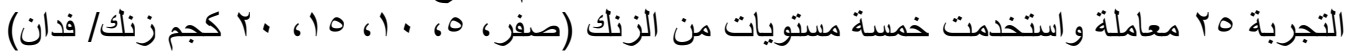

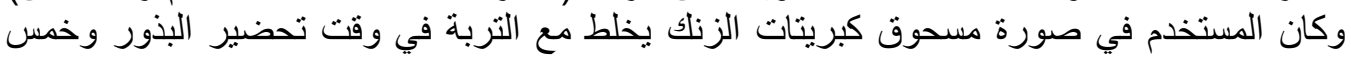

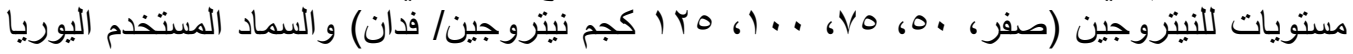

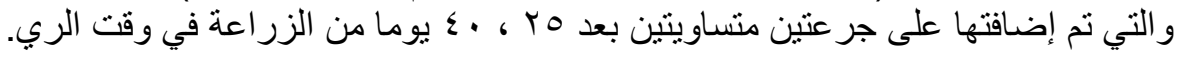

وقد بينت النتائج أن استعمال ـ ا كجم زنك للفدان كان له تأثير موجب علي إنتاجية الحبوب.

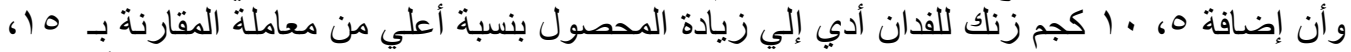

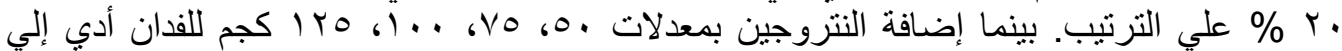

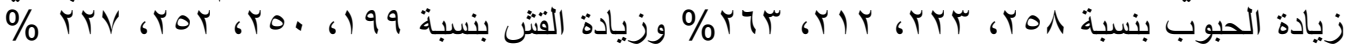

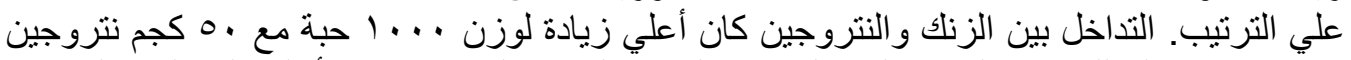

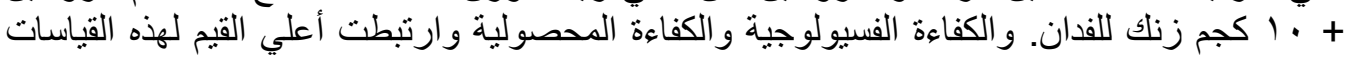

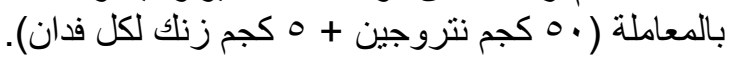

